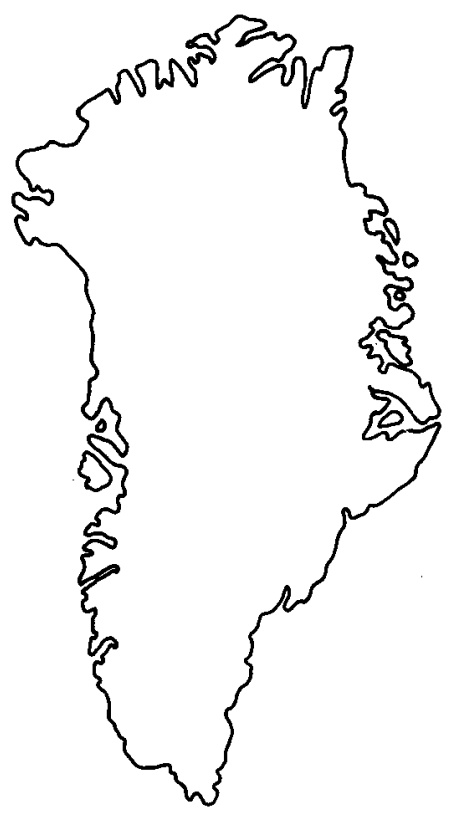

\title{
Sedimentological investigations of the Multicoloured 'series' (Eleonore Bay Group, Late Precambrian) in the Scoresby Land - Andrée Land region, North-East Greenland
}

\author{
M. Sønderholm and H. Tirsgaard
}

\begin{abstract}
The approximately $1200 \mathrm{~m}$ thick Multicoloured 'series' (bed-groups 7-13) and adjacent units of the upper Eleonore Bay Group have been the subject of detailed sedimentological investigation during 1989 in the area between northern Scoresby Land and Andrée Land in North-East Greenland. The Multicoloured 'series' consists of alternating units, 100-300 m thick, of carbonate and siliciclastic deposits which are uniformly developed throughout the central fjord zone. It represents the transitional stage from a pure siliciclastic shelf environment to a carbonate platform environment. During its development initial carbonate sedimentation was repeatedly terminated by drowning and siliciclastic deposition, until a large carbonate platform represented by the overlying Limestone-Dolomite 'series' was firmly established.
\end{abstract}

M. S. \& H. T., Geological Survey of Greenland, Øster Voldgade 10, DK-1350 Copenhagen $\mathrm{K}$, Denmark.

The Eleonore Bay Group is an approximately $14 \mathrm{~km}$ thick sequence of metasediments and sediments thought to have been deposited on an extensive shelf boardering the Iapetus Ocean during Late Precambrian times (Haller, 1971; Harland \& Gayer, 1972; Caby \& Bertrand-Sarfati, 1988). It is a fundamental element in the East Greenland Caledonian fold belt and is exposed in the region between $72^{\circ}$ and $76^{\circ} \mathrm{N}$ (fig. 1) where it forms the greater part of the pre-Caledonian sedimentary pile. There is no general agreement on a formal subdivision of the Eleonore Bay Group. At present, it is informally subdivided into the Argillaceous-Arenaceous 'series' (c. $9000 \mathrm{~m}$ of mainly quartzites and pelites), the Quartzite 'series' (c. $2500 \mathrm{~m}$ of mainly quartzites and pelites; bed-groups 1-6), the Multicoloured 'series' (c. $1200 \mathrm{~m}$ of mixed siliciclastic-carbonate deposits; bed-groups 713) and the Limestone-Dolomite 'series' (c. $1500 \mathrm{~m}$ of carbonates; bed-groups 14-20) (summarized by Haller, 1971 and Henriksen \& Higgins, 1976) (fig. 2). The present study is mainly concerned with the sedimentology of the Multicoloured 'series' which reflects the transition from siliciclastic to carbonate deposition within the basin - a transition which seems to be a worldwide phenomenon in marine sedimentary sequences of latest Precambrian age (Roberts, 1976).
In 1988 the Multicoloured 'series' was studied in its northern outcrops in Strindberg Land, Hudson Land and on Hochstetter Forland $\left(75^{\circ} \mathrm{N}\right.$ ) (Sønderholm et al., 1989). In 1989 investigations were carried on further to the south in the region between northern Scoresby Land and northern Andrée Land (fig. 1). Earlier work in this region was carried out by Lauge Koch's expeditions from 1930-1958 (Katz, 1952; Eha, 1953; Fränkl, 1953a, b; Sommer, 1957; Haller, 1958), but was mainly concerned with general mapping. During this exploratory phase sedimentological study was restricted and interpretations of sedimentary environments and basin evolution were only made in very general terms (cf. Haller, 1971). The Eleonore Bay Group was studied in the Alpefjord region and in Canning Land during field work in 1971 and 1975 by the Geological Survey of Greenland (Caby, 1972, 1976; Bertrand-Sarfati \& Caby, 1976) (fig. 1). Based on this work an environmental interpretation was presented for the Eleonore Bay Group, but without the data which would allow its critical evaluation. Continental, mainly fluvial environments were suggested for the lower two series of the group, while shallow marine environments dominated the upper two series (Caby \& Bertrand-Sarfati, 1988). 


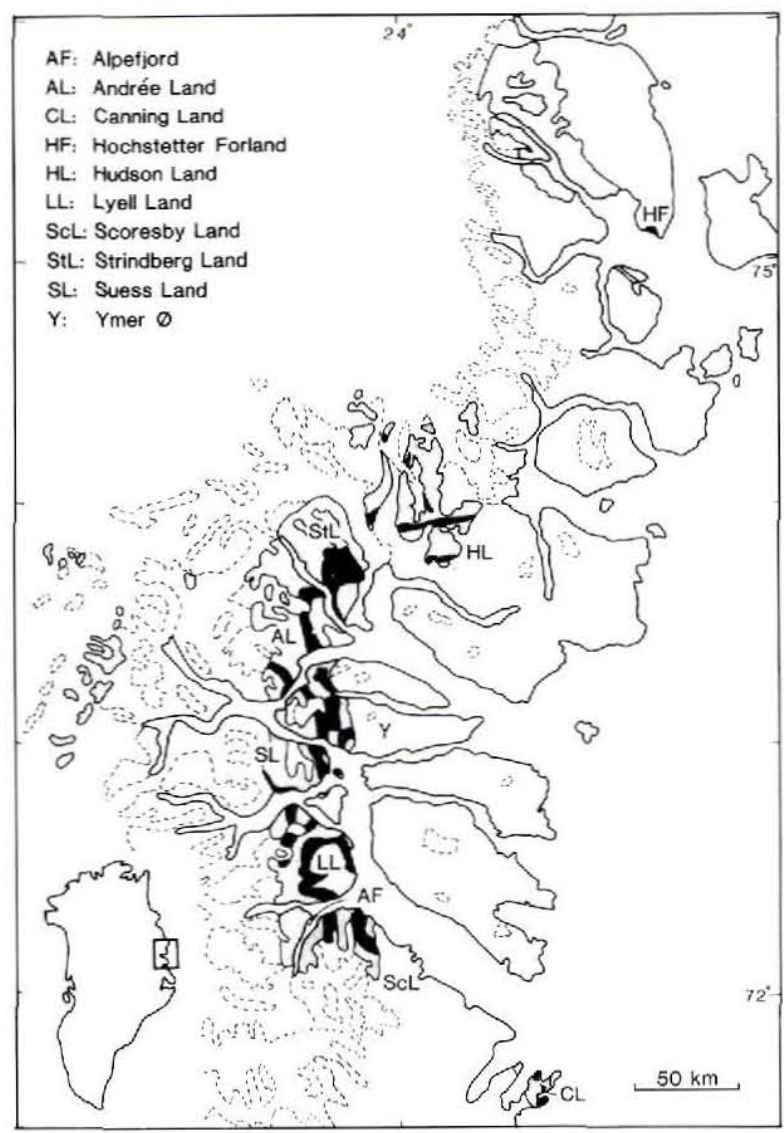

Fig. 1. Sketch map showing the distribution of the Eleonore Bay Group (dotted). The distribution of the Multicoloured 'series' is shown with black.

\section{Quartzite 'series'}

Bed-groups 1-5 of the Quartzite 'series' were not investigated in detail. They consist of alternating units of pale quartzitic sandstone and dark brown to green mudstone. Although generally well exposed, the quartzitic units are mostly massive but, judged from the relatively few sedimentary structures and the depositional architecture, a marine origin is likely (cf. Sønderholm et al., 1989). On northern Lyell Land (fig. 1) coastal exposures are of a quality which may provide a more detailed insight into the depositional evolution of this part of the Quartzite 'series'. Time, however, did not allow detailed study of these outcrops during the 1989 season. Outcrops of bed-group 6 were, however, often of a high quality, and were studied in more detail at several localities.

Bed-group $6(40-120 \mathrm{~m})$. Bed-group 6 shows considerable spacial variation. From southern Andrée Land to northern Lyell Land it consists of two distinct deposi-

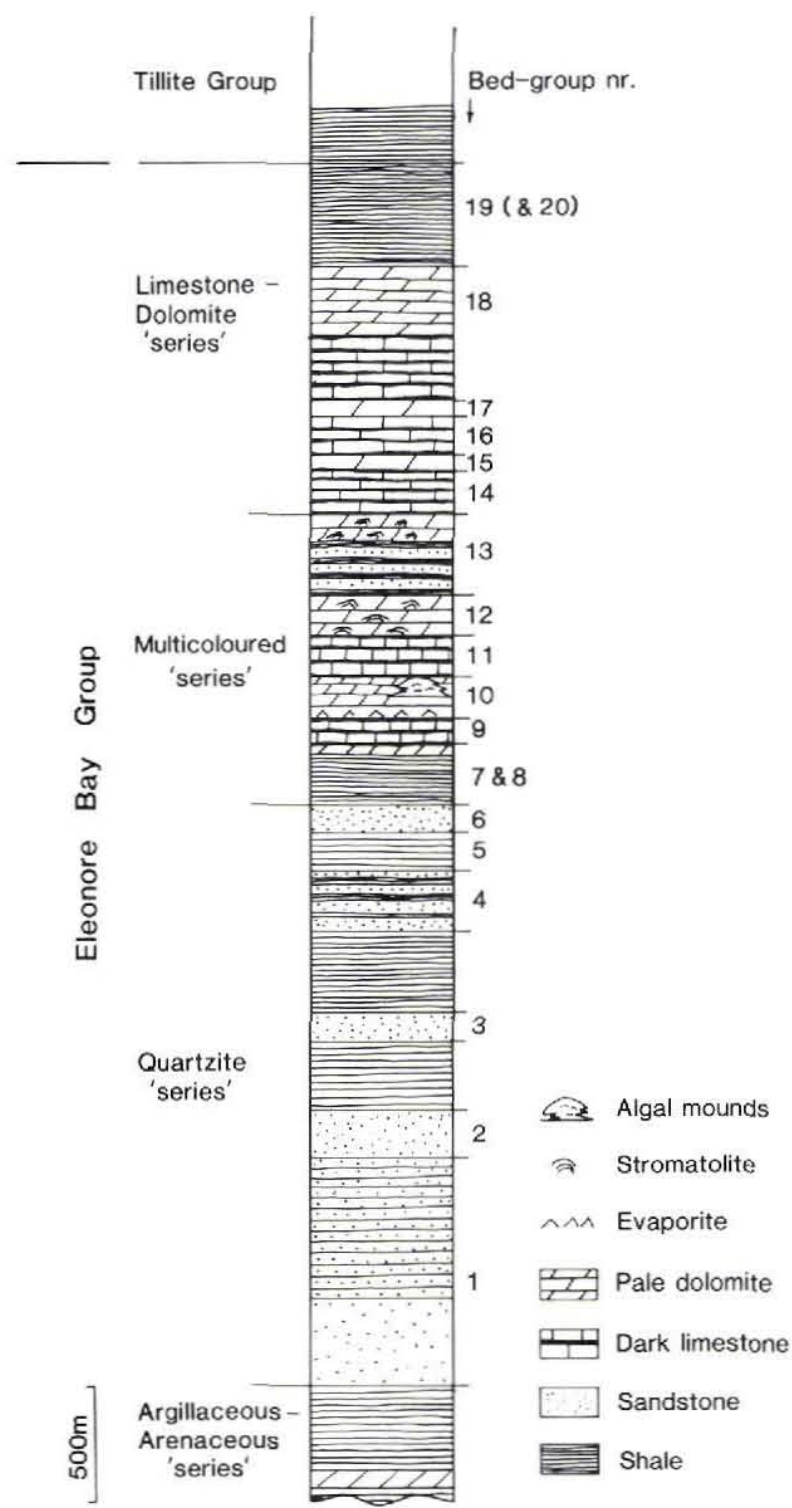

Fig. 2. Generalised stratigraphic scheme of the Eleonore Bay Group, mainly after Haller (1971).

tional units. The lower unit $(25-30 \mathrm{~m})$ consists of white, massive quartzitic sandstone alternating with dark green sandy shale. The upper unit $(80-90 \mathrm{~m})$ is a dark red to purple sandstone which, in general, shows well developed sedimentary structures, dominated by horizontal lamination with abundant mudclasts, isolated sets of planar cross-bedding, climbing-ripple lamination, desiccation cracks and numerous scour-and-fill structures (fig. 3).

The depositional architecture and sedimentary structures indicate high energy ephemeral stream deposition interacting with shallow marine sedimentation and reworking, on a broad coastal plain. Beach lamination 
Fig. 3. Scour-and-fill (S) structure associated with parallel lamination and climbing-ripple crosslamination (C) in sandstone deposited by high-energy ephemeral streams. Bed-group 6, south-eastern Andrée Land. Scale is $40 \mathrm{~cm}$.

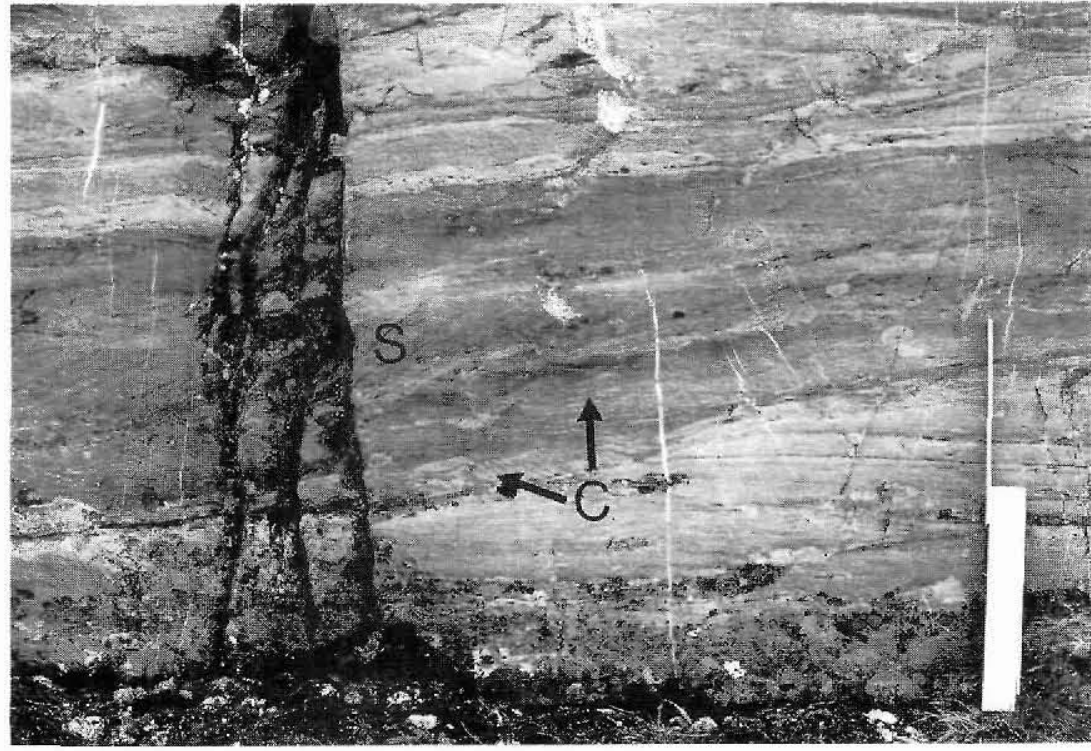

was not identified and as a consequence the exact transition from marine to fluvial deposition is extremely difficult to define. This lack of transitional facies apparently is a characteristic feature of many pre-vegetational coastal plain sequences (e.g. Dott et al., 1986).

Bed-group 6 is reduced to $40 \mathrm{~m}$ in thickness in Scoresby Land and only consists of the lower unit. Evidence of continental deposition was not found in this southern area.

\section{Multicoloured 'series'}

Bed-group 7 (210-265 m). Bed-group 7 overlies bedgroup 6 with a sharp contact and forms a conspicuous dark red to brownish-yellow unit, mainly composed of siliciclastic and carbonate mudstones. It is uniformly developed throughout the area of investigation, but is best exposed in the southern region where it also attains its largest thickness.

The lower $180-200 \mathrm{~m}$ form a general coarsening-upward sequence, interpreted as a result of an overall upward shallowing. Horizontally laminated siliciclastic mudstones gradually change to more lenticular bedded silty shales with wave-ripple cross-lamination, accompanied by $1-20 \mathrm{~cm}$ thick sandstone units, showing horizontal lamination and hummocky cross-stratification. Very spectacular soft-sediment deformation is invariably associated with the sandstone units (fig. 4). The sandstone units most likely represent storm deposits laid down below fair-weather wave base. The carbonate content of the mudstones increases upwards and, approximately 30

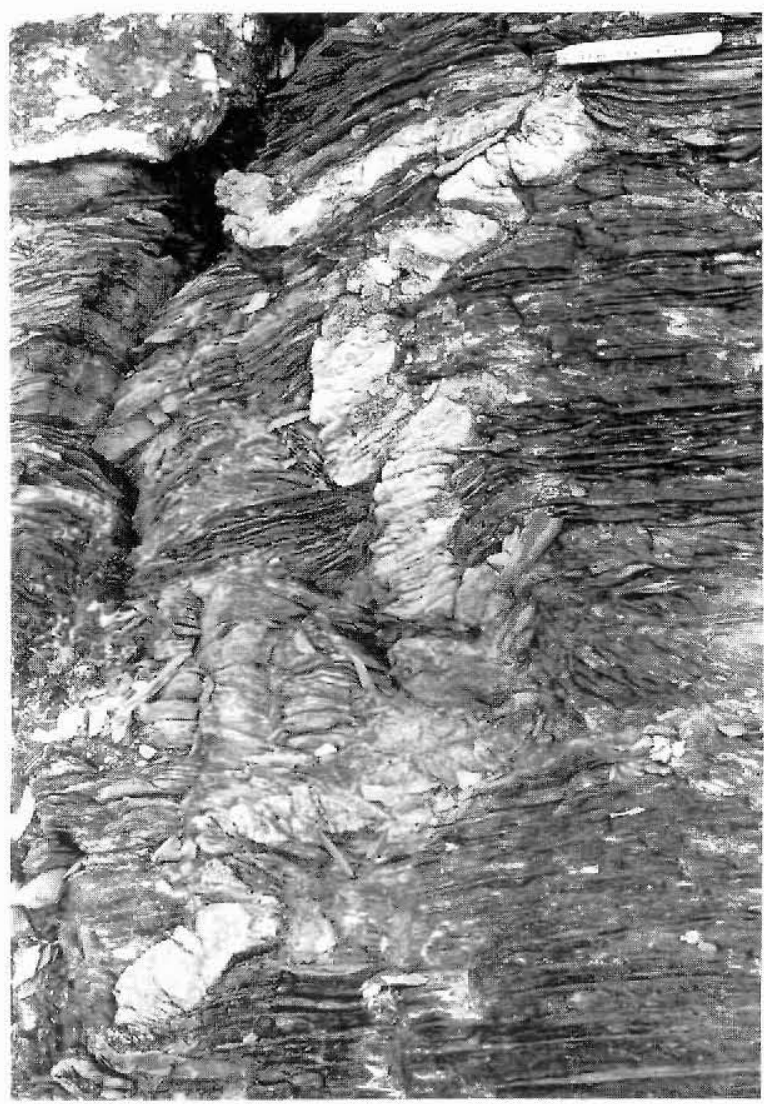

Fig. 4. Ptygmatically folded sandstone dyke in laminated mudstone. The sandstone was injected into the mudstone as a result of liquefaction of the sediment. Bed-group 7, northern Lyell Land. Scale is $20 \mathrm{~cm}$. 
$\mathrm{m}$ below the contact to bed-group 8 , the sandstone units abruptly disappear and the mudstones are almost entirely composed of dolomitic micrite. Nodular calcite of both concretionary and displacive origin is abundant in the upper part. The sudden cut-off of siliciclatic sediment supply to the shelf may be a result of climatic changes towards a more arid climate helping to establish an initial carbonate platform; the later progradational stages of this are represented by the succeeding bedgroups.

In Scoresby Land a large-scale channellized slump structure ( $>150 \mathrm{~m}$ wide and c. $25 \mathrm{~m}$ thick) containing boulder-size, partly lithified intraclasts, was observed.

Bed-group $8(10-25 \mathrm{~m})$. When observed at a distance this unit forms a conspicuous yellow-weathering band between bed-group 7 and bed-group 9. The lower boundary of bed-group 8 is difficult to define in sections as there is a very gradual transition from the red dolomitic mudstones of bed-group 7 to grey, parallel bedded, yellow-weathering, finely laminated dolomicrites of bed-group 8 . The uppermost $3-9 \mathrm{~m}$ is a transitional, but well defined, unit comprising grey, thin, wavy-bedded limestone interbedded with thin yellow-weathering laminated dolomicrites. Bed-group 8 is uniformly developed across the region, thinning towards the south.

Bed-group $9(80-130 \mathrm{~m})$. The dark limestones of bedgroup 9 are generally rather poorly exposed and mainly comprise thin to medium wavy-bedded $(3-50 \mathrm{~cm})$ massive limestone with cherty horizons. Where internal structures can be observed, the limestones are diffusely laminated, and soft sediment structures are extremely abundant (fig. 5), whereas unequivocal algal structures are rare. The upper part of bed-group 9 is dominated by $0.5-2 \mathrm{~m}$ thick beds of resedimented, probably slumped, limestones. The topmost $0.5-3 \mathrm{~m}$ consists of pale yellow-weathering dolomitic, intraclast conglomerates. Bed-group 9 is uniformly developed throughout the region, thinning towards the south, but containing increasing amounts of resedimented beds.

Bed-group $10(165-190 \mathrm{~m})$. This bed-group can be divided into three units which can all be traced throughout the region. The lower unit $(15-40 \mathrm{~m})$ has a sharp contact to bed-group 9 which it overlies with green and red massive silty dolomitic mudstones containing complex, chaotic, intraclastic conglomerates. These are overlain by an irregular interbedding of thin, rather massive pink calcite and thin stringers of red laminated silty carbonate mudstone, which grade into pale limestone with a nodular and nodular mosaic to contorted nodular mosaic texture (sensu Maiklem et al., 1969). This upper part of the unit probably represents a calcitized sulphate evaporite horizon which can be followed from Hudson Land in the north (Sønderholm et al., 1989) to Scoresby Land in the south.

The middle unit (90-105 m) begins with red, crinkly horizontally laminated dolomitic mudstones with shaly partings and occasional shallow $(<0.5 \mathrm{~cm})$ scours. The upper part of this unit comprises several cycles marked by an increasing content of thin nodular and continuous bands of green calcite, which eventually grade into limestones with a bedded nodular mosaic texture. The latter in some cases strongly resemble evaporitic deposits. The top of the middle unit consists of pale weathering parallel beds of algally laminated dolomites. In the region between northern Lyell Land and Strindberg Land

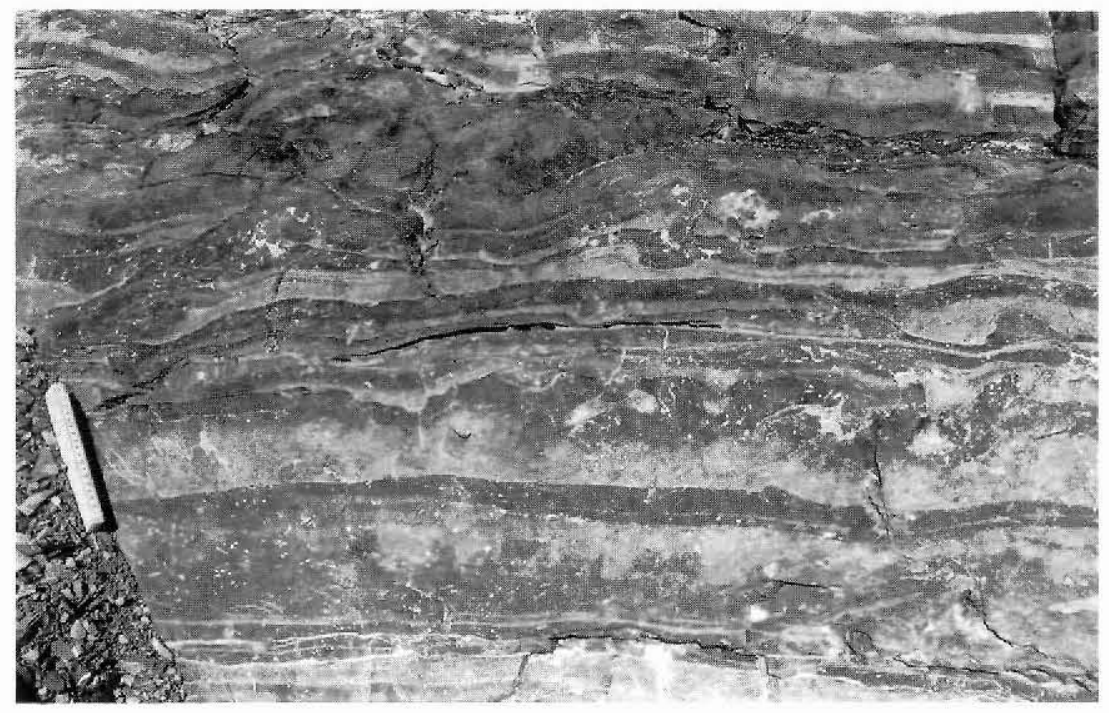

Fig. 5. Soft sediment structures in dark lime mudstone of bedgroup 9, southern Ymer $\emptyset$. Scale is $20 \mathrm{~cm}$. 


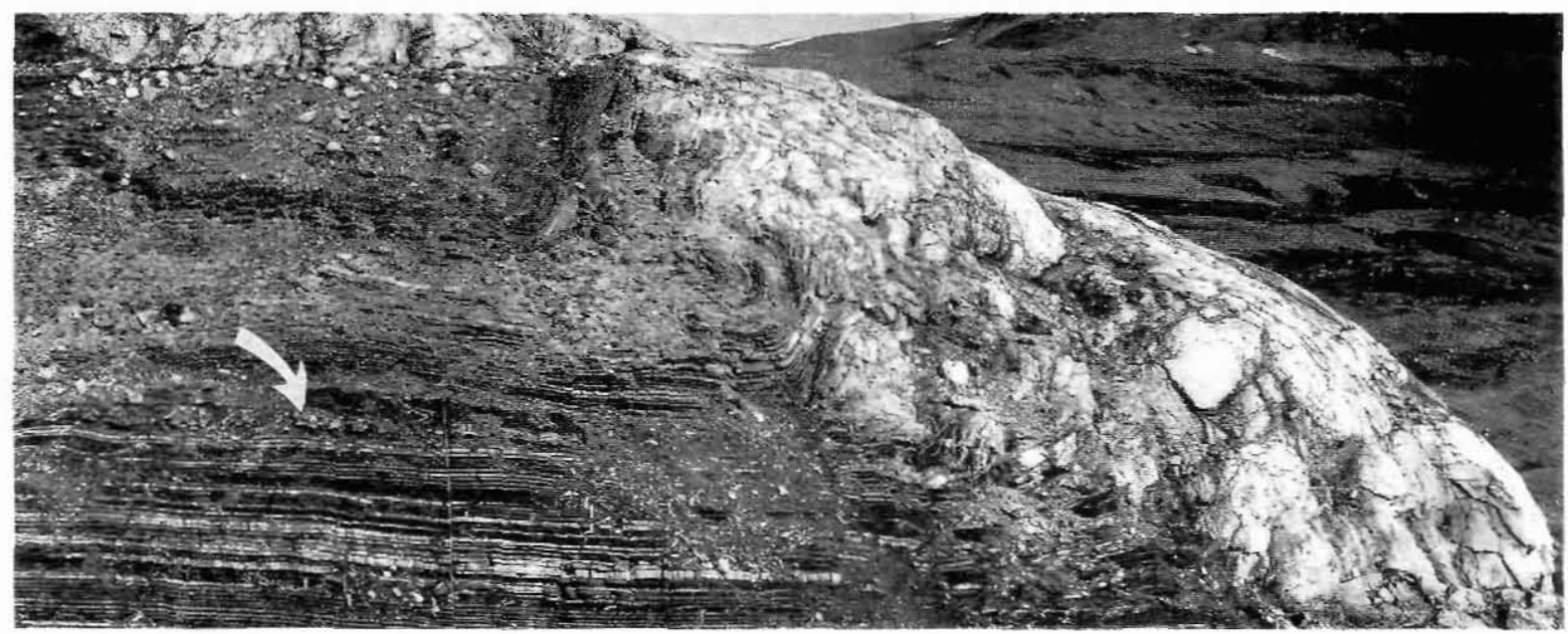

Fig. 6. Algal mound structure within upper part of bed-group 10. Arrow marks chaotic conglomerate streaming off mound. Height of mound is $35 \mathrm{~m}$. Central part of Strindberg Land.

these, however, locally swell to form small algal mounds up to $10 \mathrm{~m}$ wide and $2 \mathrm{~m}$ thick. These small mounds in a complex intergrowth form larger mound structures up to $80 \mathrm{~m}$ thick and $250 \mathrm{~m}$ wide on western Ymer $\varnothing$, in central Andrée Land and in Strindberg Land (cf. Sønderholm et al., 1989) and are surrounded and overlain by the sediments forming the upper unit.

The upper unit mainly consists of 40-50 m red-brown and orange-weathering parallel crinkly laminated dolomitic mudstones, suggesting deposition in low-energy subtidal environments. Within this unit, thick chaotic intraclastic conglomerates streaming off the large mounds show that the mounds reached into the zone of wave activity (fig. 6).

Bed-group $11(110-180 \mathrm{~m})$. This bed-group, which mainly consists of dark limestones, follows relatively sharply upon bed-group 10 . The basal part of bed-group 11 consists of black parallel to domal algally laminated limestones which upwards are interbedded with thinbedded massive lime mudstones showing abundant soft sediment and probable water-escape structures. In most areas the top of bed-group 11 also contains limestones with current-induced structures. On southern Ymer $\varnothing$ the top $30 \mathrm{~m}$ comprises black siliciclastic shales, suggesting a rather deep water environment.

A conspicuous white dolomitic band c. $10 \mathrm{~m}$ thick occurs close to the top of the bed-group in southern Suess Land and in northern Lyell Land. At the latter locality it consists of intergrown $5-10 \mathrm{~m}$ wide and c. $2 \mathrm{~m}$ high steeply domed algal bioherms.

Bed-group $12(150-200 \mathrm{~m})$. This often rather poorly exposed bed-group consists of pale grey stromatolitic dolomite, weathering conspicuously orange in the upper part. It forms a shallowing upwards sequence from generally shallow subtidal to intertidal environments. The lower approximately $100-150 \mathrm{~m}$ of the bed-group consists of $0.5-2 \mathrm{~m}$ thick rather irregular wavy beds composed of stromatolitic mound and intermound sediments. The mounds are mostly built by cylindrical to turbinate stromatolites $10-40 \mathrm{~cm}$ high and $5-15 \mathrm{~cm}$ wide, often with rather irregular branching, set in a micritic matrix. These mounds are considered to be of low energy, shallow subtidal origin. The orange weathering top of the bed-group consists of thinner $(0.3-1 \mathrm{~m})$ stromatolitic and algally laminated beds, separated by green and red shales. The stromatolites are often strongly influenced by current activity and surrounded by intraclastic conglomerates. Dessication cracks in the algal-laminates indicate intermittent subaerial exposure. Shallow, periodically high energy environments point to a lower intertidal depositional regime.

On southern Ymer $\varnothing$, where the top of bed-group 11 is of rather deep water origin, the lower part of bedgroup 12 also suggests similar environments. Stromatolites are dominated by closely packed, up to $2 \mathrm{~m}$ high Conophyton set in a micritic matrix together with algallaminated beds and broad domal stromatolites (fig. 7). Stromatolites of this type and growth fashion have until now only been described from low energy subtidal settings (Donaldson, 1976; Grotzinger, 1989). Upwards Conophyton have a wider spacing and are set in micritic to intraclastic conglomerate matrix, suggesting higher energy, shallow subtidal environments.

Bed-group $13(270-290 \mathrm{~m})$. Bed-group 13 marks a temporary return of dominantly marine, siliciclastic deposi- 


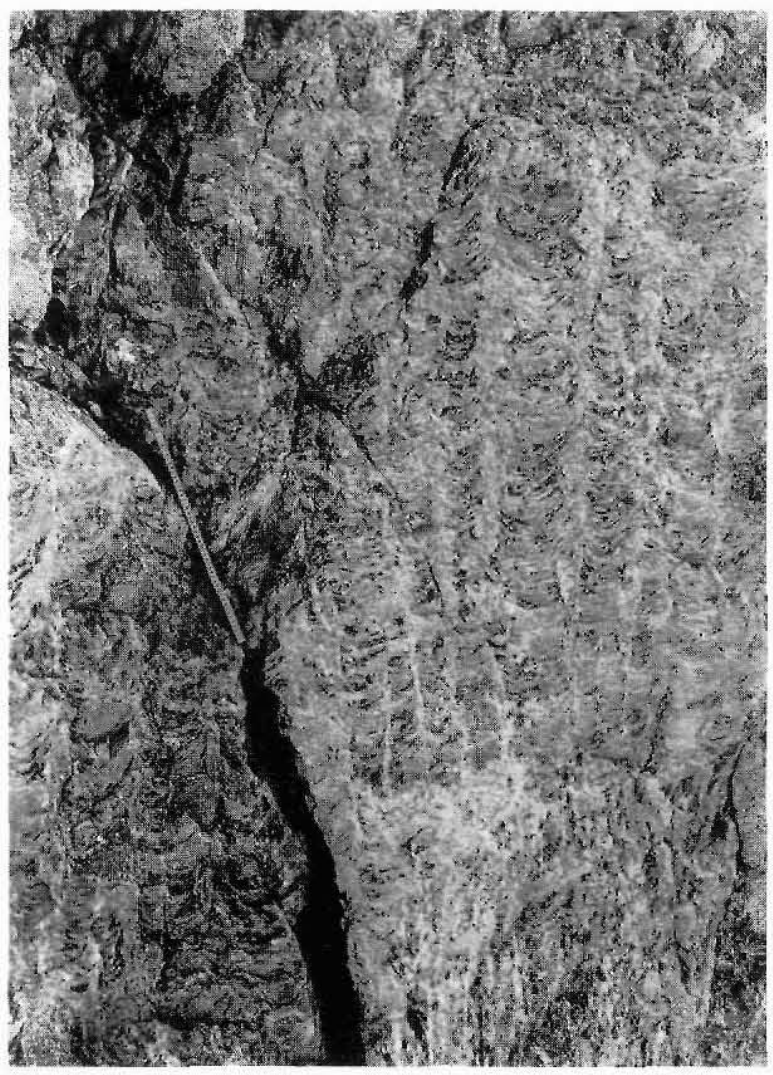

Fig. 7. Closely packed conophytons, showing lateral linkage, upwards uniformity in column diameter and lack of intercolumn detritus. Lower part of bed-group 12, southern Ymer $\varnothing$. tion. The contact to bed-group 12 is sharp, marking an abrupt change from shallow water carbonate deposition to deep water siliciclastic mudstone deposition. The lower $225-250 \mathrm{~m}$ roughly consists of $50-100 \mathrm{~m}$ thick coarsening-upward units. These consist of black mudstone with $1-40 \mathrm{~cm}$ thick quartzitic beds containing hummocky cross-stratification and parallel lamination, passing into $5-20 \mathrm{~m}$ thick pale green quartzitic sand sheets. Each unit is capped by $2-15 \mathrm{~m}$ of yellow dolomitic, stromatolite biostromes (fig. 8), some of which can be followed throughout the entire region. The coarsening-upward units are composite in nature comprising stacked, $10-30 \mathrm{~m}$ thick coarsening-upward sequences which lack the biostromal capping.

Bed-group 13 is terminated by approximately $30 \mathrm{~m}$ of alternating $30-200 \mathrm{~cm}$ thick beds of carbonate, sandstone and red and green mudstone. The carbonate beds are mainly composed of flat pebble conglomerate, edgewise conglomerate and calcarenite, but algal-laminated beds and stromatolites are also common. Locally desiccation cracks and tepee structures were observed, indicating periodic emergence. The sandstone beds mainly contain horizontal lamination and ripple crosslamination. An intertidal, locally supratidal origin seems most likely for these carbonate-siliciclastic sediments which mark the initial re-establishment of a carbonate platform and the termination of the Multicoloured 'series'.

The stromatolitic biostromes within bed-group 13 are

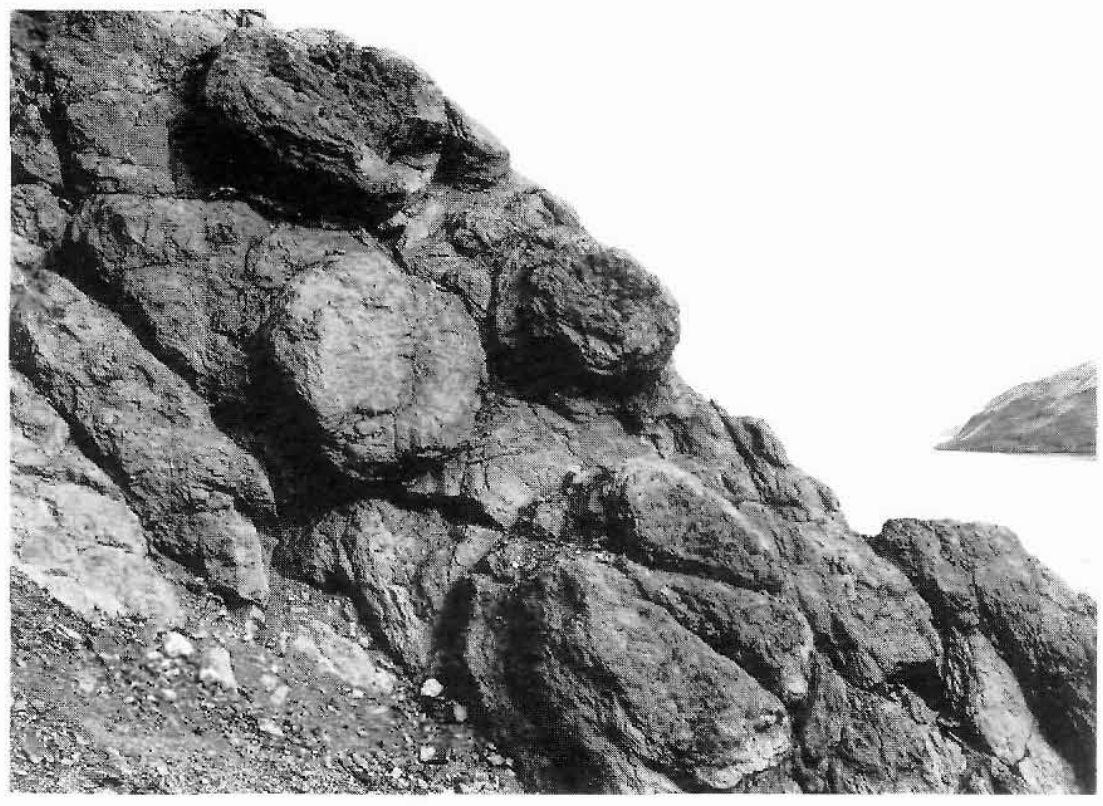

Fig. 8. Stromatolite biostrome with small mounds on top. Upper part of bed-group 13, southern Ymer $\varnothing$. The upper mound to the left is $150 \mathrm{~cm}$ in diameter. 
in general best developed in the northern region and partly wedge out towards the south. The change is accompanied, by an increasing content of sandstone at the expense of both carbonate and mudstone. This is most pronounced in northern Lyell Land where several biostromal units are entirely missing. In Scoresby Land, however, a return to more carbonate rich sediments occurs.

\section{Limestone-Dolomite 'series'}

Bed-group $14 a(25-50 \mathrm{~m})$. Above the red and green mudstones and sandstones marking the top of bedgroup 13 , a 5-10 $\mathrm{m}$ thick pale weathering stromatolitic unit occurs. The lower part generally shows well developed dolomitic stromatolite mounds up to $3 \mathrm{~m}$ thick and $25 \mathrm{~m}$ wide, overlain by a mixed sequence of dark grey thin-bedded internally massive limestones and thin dolomitic flat-pebble conglomerates. Upwards they grade into wavy, thin-bedded, black, internally massive limestones with $10-80 \mathrm{~cm}$ thick beds of strongly erosive matrix-supported intraclastic conglomerates. These sediments were deposited in generally low energy environments which, however, were periodically influenced by storms. The content of conglomerates increases upwards and in Scoresby Land the top $5 \mathrm{~m}$ consists of cross-bedded calcarenites and calcirudites.

Bed-group $14 b(15-30 \mathrm{~m})$. In northern Andrée Land and Strindberg Land, bed-group $14 \mathrm{~b}$ is dominated by an alternation of up to $150 \mathrm{~cm}$ thick, lenticular bedded chaotic and vaguely graded rip-up conglomerates (fig. 9), occasionally showing stone-rosette structures, and pale yellow, pink and white calcitic mudstones, some of which show vague resemblance to the lower evaporitic unit of bed-group 10. Towards the south rip-up conglomerates become less abundant and bed-group $14 \mathrm{~b}$ is totally dominated by stromatoid bioherms. The sediments of bed-group 14b thus indicate high energy intertidal to supratidal (possibly evaporitic) environments to the north and low energy shallow subtidal environments to the south, reflecting an accretion of the carbonate platform following the transgression at the initiation of the Limestone-Dolomite 'series'.

\section{Concluding remarks}

Periodic changes in sea-level, sediment influx and, perhaps less likely, subsidence rates during deposition of the Multicoloured 'series' resulted in the formation of cyclic alternations of shale, sandstone and carbonate units. These cycles formed on a number of scales, varying from metres to hundreds of metres in thickness. During the initial stages of carbonate sedimentation, carbonate platform formation apparently was highly vulnerable to eustatic, and possibly climatic variations which continuously changed the balance between carbonate production and siliciclastic sedimentation. Overall conditions, however, did favour carbonate production, leading to the establishment of an extensive, more permanent and stable carbonate platform, represented by the succeeding $c .1500 \mathrm{~m}$ thick Limestone-Dolomite 'series' of the Eleonore Bay Group.

Acknowledgements. Henrik Tirsgaard's participation in the project is financed by the Danish Natural Science Reseach Council, Grant No. 11444.
Fig. 9. Erosively based matrixsupported intraclastic conglomerate near top of bed-group $14 \mathrm{~b}$. Note the giant oncoid in fower left corner of picture (arrowed). The oncoid is $35 \mathrm{~cm}$ long and 10 $\mathrm{cm}$ thick, and coated by concentric algal lamination. Central Ymer $\varnothing$.

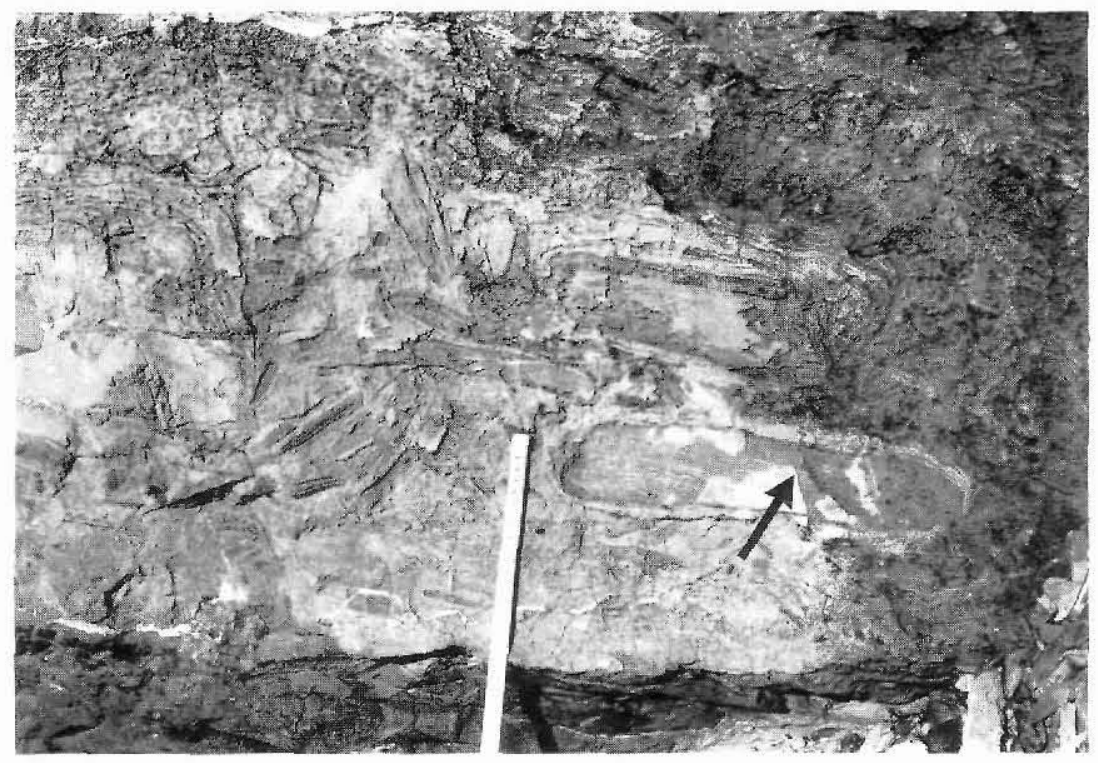




\section{References}

Bertrand-Sarfati, J. \& Caby, R. 1976: Carbonates et stromatolites du sommet du Groupe d'Eleonore Bay (Précambrien terminal) au Canning Land (Groenland oriental). Bull. Grønlands geol. Unders. 119, $51 \mathrm{pp.}$

Caby, R. 1972: Preliminary results of mapping in the Caledonian rocks of Canning Land and Wegener Halv $\emptyset$, East Greenland. Rapp. Grønlands geol. Unders. 48, 21-38.

Caby, R. 1976: Investigations on the lower Eleonore Bay Group in the Alpefjord region, central East Greenland. Rapp. Grønlands geol. Unders. 80, 102-106.

Caby, R. \& Bertrand-Sarfati, J. 1988: The Eleonore Bay Group (central East Greenland). In Winchester, J. A. (edit.) Later Proterozoic stratigraphy of the northern Atlantic regions, 212-236. Glasgow: Blackie and Son Ltd.

Donaldson, J. A. 1976: Paleoecology of Conophyton and associated stromatolites in the Precambrian Dismal Lakes and Rae Groups, Canada. In Walter, M. R. (edit.) Stromatolites, 523-534. Developments in Sedimentology 20. Amsterdam: Elsevier.

Dott, R. H. Jr, Byers, C. W., Fielder, G. W., Stenzel, S. R. \& Winfree, K. E. 1986: Aeolian to marine transition in Cambro-Ordovician cratonic sheet sandstones of the northern Mississippi valley, U.S.A. Sedimentology 33, 345-367.

Eha, S. 1953: The pre-Devonian sediments on Ymers $\emptyset$, Suess Land, and Ella $\varnothing$ (East Greenland) and their tectonics. Meddr Grønland 111(2), 105 pp.

Fränkl, E. 1953a: Geologische Untersuchungen in Ost-Andrées Land (NE-Grønland). Meddr Grønland 113(4), 160 pp.
Fränkl, E. 1953b: Die geologische Karte von Nord-Scoresby Land (NE-Grønland). Meddr Grønland 113(6), $56 \mathrm{pp.}$

Grotzinger, J. P. 1989: Facies and evolution of Precambrian carbonate depositional systems: emergence of the modern platform archetype. In Crevello, P. D., Wilson, J. L., Sarg, J. F. \& Read, J. F. (edit.) Controls on carbonate platform and basin development. Soc. Econ. Paleont. Miner. Spec. Publ. 44, 79-106.

Haller, J. 1958: Der 'Zentrale Metamorphe Komplex' von NE-Grönland. II. Die geologische Karte der Staunings Alper und des Forsblads Fjordes. Meddr Grønland 154(3), 153 pp.

Haller, J. 1971: The geology of the East Greenland Caledonides, 413 pp. London: Interscience Publishers.

Harland, W. B. \& Gayer, R. A. 1972: The Arctic Caledonides and earlier oceans. Geol. Mag. 109, 289-314.

Henriksen, N. \& Higgins, A. K. 1976: East Greenland Caledonian fold belt. In Escher, A. \& Watt, W. S. (edit.) Geology of Greenland, 182-246. Copenhagen: Geol. Surv. Greenland.

Maiklem, W. R., Bebout, D. G. \& Glaister, R. P. 1969: Classification of anhydrite - a practical approach. Bull. Can. Petrol. Geol. 17, 194-233.

Roberts, J. D. 1976: Late Precambrian dolomites, Vendian glaciation, and synchroneity of Vendian glaciations. J. Geol. $84,47-63$.

Sommer, M. 1957: Geologie von Lyells Land (NE-Gröland). Meddr Grønland 155(2), $157 \mathrm{pp}$.

Sønderholm, M., Collinson, J. D. \& Tirsgaard, H. 1989: Stratigrafic and sedimentological studies of the Eleonore Bay Group (Precambrian) between $73^{\circ} 30^{\prime} \mathrm{N}$ and $76^{\circ} \mathrm{N}$ in East Greenland. Rapp. Grønlands Geol. Unders. 145, 97-102. 